\title{
Analysis of the Role of Organizational Culture at the Cen- ter for Employee Education and Training
}

\section{Análisis del papel de la cultura organizacional en el Centro de Educación y Formación de Empleados}

Dedy Achmad Kurniady* (1)
Universitas Pendidikan Indonesia, Indonesia

ORCID: https://orcid.org/0000-0003-1120-8133

\section{Sedarmayanti}

Universitas Dr. Soetomo Surabaya, Indonesia

ORCID: https://orcid.org/0000-0002-7854-9904

Mulyaningsih

Universitas Garut, Indonesia

ORCID: https://orcid.org/0000-0001-8740-5454

Maity Rubianty

STIA LAN Bandung, Indonesia

ORCID: https://orcid.org/0000-0003-3361-6170

Aan Komariah

Universitas Pendidikan Indonesia, Indonesia

ORCID: https://orcid.org/0000-0003-4495-5792

\section{Sururi}

Universitas Pendidikan Indonesia, Indonesia

ORCID: https://orcid.org/0000-0002-9968-6529

Cicih Sutarsih

Universitas Pendidikan Indonesia, Indonesia

ORCID: https://orcid.org/0000-0003-2499-7581

Ipong Dekawati

Universitas Wiralodra, Indonesia

ORCID: https://orcid.org/0000-0002-6231-1125

Fahmi Idris

Universitas Negeri Jakarta, Indonesia

ORCID: https://orcid.org/0000-0002-0172-5308

Betty Riadini

Lembaga Ilmu Pengetahuan Indonesia, Indonesia

ORCID: https://orcid.org/0000-0001-7241-4833

Syifa Hanifa Salsabil

Telkom University, Indonesia

ORCID: https://orcid.org/0000-0002-8872-2651

Putri Maulida Kurniasari

Universitas Pendidikan Indonesia, Indonesia

ORCID: https://orcid.org/0000-0002-9496-1624 
Received 06-14-20 Revised 08-10-20 Accepted 09-01-20 On line 09-30-20

\section{*Correspondence}

Email: dedy_achmad@upi.edu
Cite as:

Kurniady, D.A., et al., (2020). Analysis of the Role of Organizational Culture at the Center for Employee Education and Training. Propósitos y Representaciones, 8 (SPE3), e773. Doi: http://dx.doi.org/10.20511/pyr2020.v8nSPE3.773

(c) Universidad San Ignacio de Loyola, Vicerrectorado de Investigación, 2020.

(cc) EY-NC-N0 This article is distributed under license CC BY-NC-ND 4.0 International (http://creativecommons.org/licenses/by-nc-nd/4.0/)

\section{Summary}

The purpose of this study was to analyze the role of organizational culture at Bandung Regional Ministry of Education and Training Center. This research was conducted with a descriptive research method with a qualitative approach. The data were collected through interview, observation, and document review. The analysis results showed the following(1) Organizational culture seen from the aspect of providing a sense of identity, a role in an effort to arouse commitment to the organization's mission and its role in clarifying the standard of behavior has not played an optimal role one of them do not use complete attributes and do not use uniforms according to the rules (2) The obstacle in implementing organizational culture at Bandung Regional Ministry of Education and Training Center is that there are still employees who are more concerned with personal interests so that work is often neglected. Many employees are still lazy to follow the flag ceremony. (3) The efforts made by the Bandung Regional Ministry of Education and Training Center to discipline employees by distributing examples of uniformed rules that are correct in accordance with the rules, direct supervisor approach to be able to foster subordinates to work better.

Keywords: organizational culture, training centre, ministry of internal affairs.

\section{Resumen}

El propósito de este estudio fue analizar el papel de la cultura organizacional en el Centro Regional de Educación y Capacitación de Bandung. Esta investigación se realizó con un método de investigación descriptivo con enfoque cualitativo. Los datos se recopilaron mediante entrevistas, observación y revisión de documentos. Los resultados del análisis mostraron lo siguiente (1) La cultura organizacional vista desde el aspecto de proporcionar un sentido de identidad, un papel en un esfuerzo por despertar el compromiso con la misión de la organización y su papel en aclarar el estándar de comportamiento no ha jugado un papel óptimo. de ellos no usan atributos completos y no usan uniformes de acuerdo con las reglas (2) El obstáculo para implementar la cultura organizacional en el Centro Regional de Educación y Capacitación de Bandung es que todavía hay empleados que están más preocupados por los intereses personales para que trabajen a menudo se descuida. Muchos empleados todavía son perezosos para seguir la ceremonia de la bandera. (3) Los esfuerzos realizados por el Ministerio de Educación y Centro de Capacitación de la Región de Bandung para disciplinar a los empleados mediante la distribución de ejemplos de reglas uniformadas que son correctas de acuerdo con las reglas, 
enfoque de supervisor directo para poder fomentar que los subordinados trabajen mejorpoéticas suyas, a saber, "Safarnameye Gerdbad", "Boradeha" y "Noushdaruy- e-Tarhe-Genérico ".

Palabras clave: cultura organizacional, centro de formación, ministerio del interior

\section{Introduction}

Each organization has a distinctive characteristic that distinguishes it from other organizations (Cristina B. Gibson, Julian Birkinshaw, Dana McDaniel Sumpter, and Tina Ambos, 2019). This characteristic is the identity of the organization, called the organizational culture. Organizational culture refers to the unique relationship of norms, values, beliefs, and the manner of behavior that characterizes how groups or individuals are getting things done. Organizational culture contains values that must be understood, be imbued, practiced together by all individuals or groups involved therein. Culture relates to how the organization builds a commitment to realizing the vision, calming the hearts of customers/stakeholders, winning the competition, and building the strength of the organization. According to Danquah, Derrick Opoku., Amankona, David., Amo, Seth Adutwum., Belinda, Bonney (2018), culture determines the progress of each organization, no matter the type of organization.

Establishing a strong culture organization requires a process because of changes occurring in the organization concerning the change of people who are in the organization including differences in perception, desire, attitude, and behavior. Conformity between organizational characteristics and the wishes of employees must be achieved which leads to a high level of togetherness. In preparing the changes, employees are expected to feel safe and happy in doing their work. As such, employees will be willing to accept the changes sincerely without fear or resorted. In line with this, it can be understood that organizational culture has a crucial role in improving job satisfaction and organizational performance. Organizational culture is a culture that is within the organization consisting of many intangible phenomena such as values, beliefs, assumptions, and patterns of behavior (Ernesto, Knein., Greven, Andrea., Bendig, David., Brettel, Malte., 2020). Culture is an invisible and untracked power that always lies behind the organizational activity that can be seen and monitored.

The performance of an organization is determined by the human resources in it. Human resources have high motivation, creativity, and able to develop innovations that will make human resource performance better. Therefore, it takes effort to improve human resources (Al Nasser, A. H., \& Jais, J, 2020). Employee performance is an achievement/effectiveness at the employee/employment level influenced by job objectives, job design, job management, and individual characteristics (Manik, Ester, 2016).

\section{Organizational Culture}

In some literature, the term of use of corporate culture is commonly replaced with the term organizational culture. Both of these terms have the same understanding. Therefore in this study, the term is used equally and both have the same way of understanding. According to Duncan (2008), Önday, Özgür. (2016), corporate culture or organizational culture how to think and do something that is tradition embraced jointly by all members of the organization and new members must study or at least accept it partly so that they are accepted as part of the organization.) Sutrisno (2010) mentions that organizational culture is defined as a set of value systems, beliefs, assumptions, or norms that apply to agreed and followed by members of an organization as a guideline for the conduct and problem solving of its organization. Ahmad Sun'an (2010) mentions that organizational culture is a form of an effort to obtain the sense, feeling, atmosphere, character, or imagery of an organization that has a strong institutional culture and the basic fun- 
ctions of leadership to form an organizational culture. While the Trujillo Pacanowsky in Morissan (2009) gives an understanding of the organizational culture as a way of life in the organization. Belonging to the culture of the organization is an emotional and psychological climate or atmosphere that includes morals, attitudes, and productivity levels of members. The organizational culture also includes all the existing symbols and meanings given to the symbol. The meaning and significance of the organizational culture that exists in the members of the organization do not exist by itself, but through the process, interaction, and communication between members of the organization.

If the description of the organization's cultural understanding is expressed by the experts, that is the dynamist of the organization caused by the behavior of the members of the organization that can differ to create a dysfunctional conflict so that with the organization culture that solves it, makes conducive to high performance. Therefore, organizational culture is not only applicable to the company, but all forms of the organization both corporate, public, and social. When differentiated, the difference is its direction, that is, the company is directed at an effort to gain profit but the public organization is directed to better service efforts. Organizational culture is a dynamist and gives the meaning of organizing the organization's activities to achieve its objectives. The process of creating organizational culture according to Robbins (2007), visualized in Figure 1.

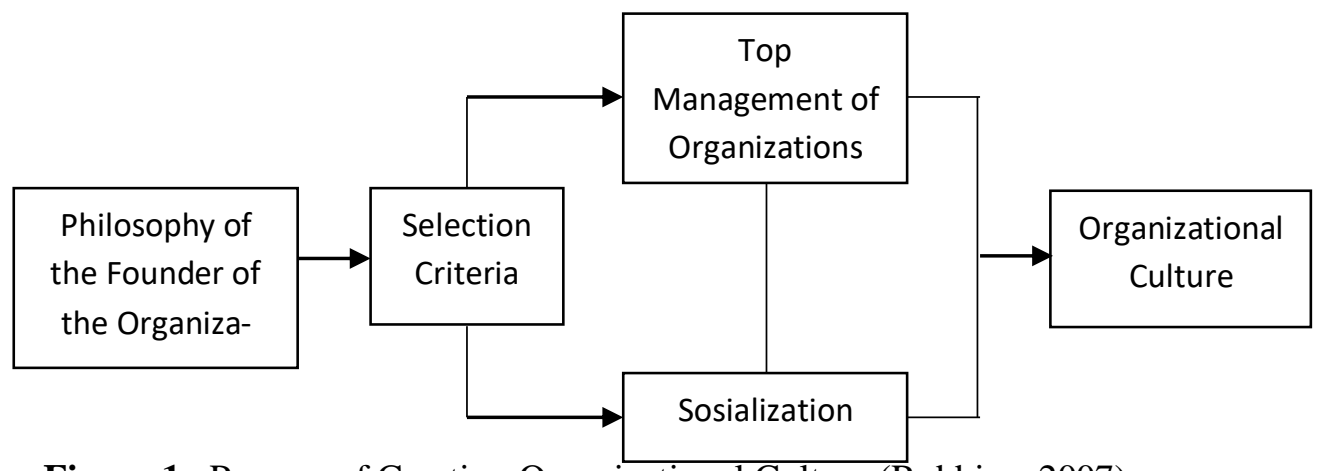

Figure 1. Process of Creating Organizational Culture (Robbins, 2007)

Robbins (2007) suggests if the organization does not have a dominant culture and consists of only a lot of sub-cultures, the influence of culture on the effectiveness of the Organization will be much less obvious because there will be no consistency in perception or behavior.

The sense of the organizational culture expressed by the experts above, although the formula is different between the other experts, there are essentially three things that become essential to the organizational culture sense, namely: (1) does not appear by itself but rather formed and studied; (2) A set of values or ideas and beliefs embraced together; (3) Influence the interaction of the Organization and can be inherited from generation to generation. Based on the above definition of understanding, it is obvious that the purpose of the organization's cultural implementation is for all individuals in the organization to comply and be guided by the organizational values of beliefs and norms in the organization, thus making a bond of togetherness in interacting towards the achievement of the intended objectives (organizational effectiveness).

Gibson (1995) distinguishes a strong and weak culture, a strong culture is demonstrated by organizational value reflected in the behavior of officers. The bigger value that employees receive, the stronger the organizational culture, the more visible the influence on the behavior of employees. Strong cultures are formed due to strong values and leadership styles. A strong organizational culture will trigger employees to think, behave, and behave according to 
organizational value. The conformity between organizational culture and its members of the organization will lead to job satisfaction, encouraging employees to improve their performance better.

The strength of the organizational culture impacts job satisfaction, employee performance, and overall organizational performance, therefore organizations need to have a strong organizational culture grown. Suyono (2004) reveals several factors to foster organizational culture: 1) Leadership, organization must have leaders that can be exempted and heard by subordinates; 2) Communication, the process of communication must be implemented consistently and routinely so that cultural differences (habits) brought in different individual background will experience the integration of equations with the objectives of the Organization; 3) Motivation, motivation is the granting of spirit and create the excitement of someone's work so that they will cooperate, work effectively and integrate with all efforts to achieve satisfaction.

In line with this opinion Robert and Angelo (2001) mention three important definitions of organizational culture characteristics, namely: 1) Organizational culture is given to new employees through a process of socialization; 2) Organizational culture influences our behavior at work; 3) Organizational culture applies at two different levels. In general, it is more difficult to change the culture in an already-ripe organization than creating it. Robbins (2007) is of the view that organizational culture affects the competitive edge of organization. When the objective factor is perceived equally by all employees so as to form the organizational culture, the culture that will be generated later can be a strong culture and weak culture, which will further impact the performance and satisfaction of work.

Organizations must have a value that has been believed to be high, and become the driving force by most members of the organization as a legitimate main rule to achieve the desired objectives. Greenberg and Baron (2003) mention that there are three organizational cultural roles: 1) Culture gives sense of identity, 2) Culture rises commitment on organization's mission, 3) Culture clarify and strengthening behavior standard. With reference to the 3 (three) roles of organizational culture put forward by Greenberg and Baron, the author compiles a conceptual model that forms the basis of research as follows:

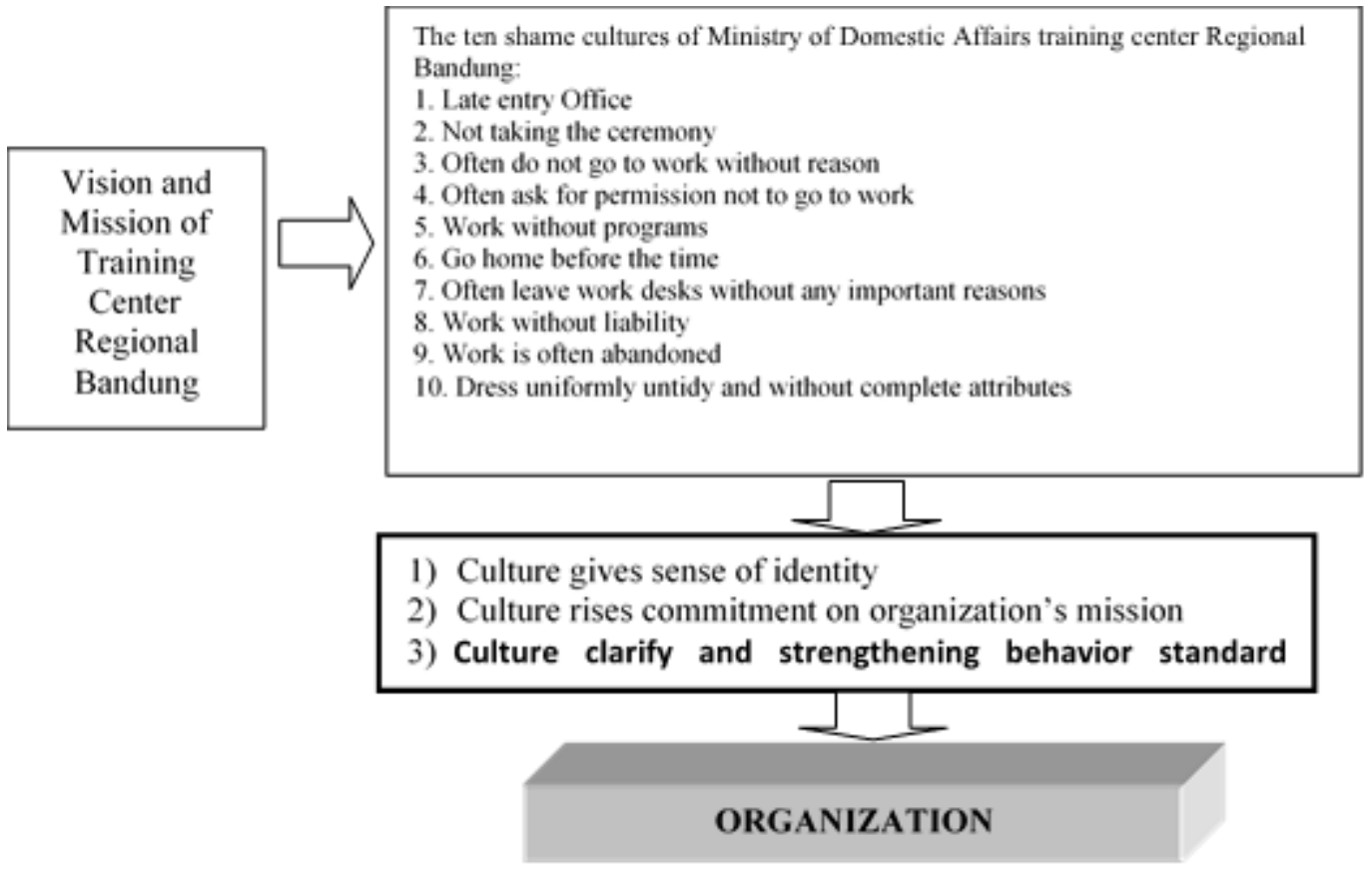


Figure 2. Conceptual Model Source: Greenberg and Baron (2003)

\section{Method}

Research on cultural analysis of the organization at Ministry of Home Affairs Training Center Regional Bandung was using qualitative research design. The focus of research was not only on results and the process of achieving results from the role of organizational culture in improving employee performance at Ministry of Home Affairs Training Center Regional Bandung, but also other aspects that also contributed to the achievement of the results. Other aspects were seen such as human resources, facilities and infrastructure training.

In conducting this research, the technique of data collection that authors did was 1) an open and structured interview, 2) documentation of data from several statutory regulations as well as other related documents such as: Data of current officer condition of the Personnel Section, vision and mission of the Ministry of Home Affairs Training Center Regional Bandung, the recap of personnel attendance from the Personnel Section, letter or Memorandum of service issued by personnel, 3) Directly observation of the role of organizational culture in Ministry of Home Affairs Training Center Regional Bandung. The Data was analyzed by display, analyzing and conclusion.

\section{Results}

\section{The Role of Culture in Giving Sense of Identity}

The interview was conducted with the head of the Ministry of Home Affairs Training Center, head of Administration division and staff of the Training Center, officers to know about the provision of information on the organization's uniform usage rules clearly to all employees. Interview results with the head of Training Center said: "The rules in Training Center, Regional Bandung are informed even the rules are not only issued by Training Center, Regional Bandung but by Jakarta Employment Bureau and the letter was already there". (Interview date 15 October 2019)

As head of Training Center, said the rule of use information was quite clearly conveyed through ceremonial activities and through circular letter number 025/4660/SJ on June 12, 2019.

The same question is asked by the head of the Administration division about uniform usage. The Personnel Section has informed the rules of use of uniforms and their attributes through a memorandum of service and has informed consequences for those who violate the rules. In the greeting at the flag ceremony we often inform repeatedly but in the implementation of employees are difficult to follow properly the rules that have been set.

As head of the training center said, the head of the Administration division said information is always delivered at every Monday flag ceremony. But officials were still difficult to follow the rules set in their circular letters, they still follow personal desires in dressing. They prefer their style to follow the rules. That employees prefer to use uniforms as they wish. The attribute was rarely used because of laziness to use attributes.

In the use of such attributes, some very many employees did not use the full attribute. They used the full attribute only when ceremonies only, sometimes at ceremonies they often forget to use kopiah mainly there were female As instructed from the center of the officer who did not use the complete attributes of the ceremony was separated in the rightmost row but in the implementation in the training center Regional Bandung employees who did not use the full attributes were never separated from the line and there was never a uniform attribute check. 


\section{The Role of Culture in Rising Commitment for Organization Mission}

Commitments in the organization other than those seen from working without the program can be seen also in the daily work whether employees often leave behind their unfinished work or leave employment for a long period of personal interest. As asked head of training center about his loyalty to organizations that were more concerned with the organization's interests than personal interests.

In the organization, the interest of the Organization must take precedence over personal interests however the work must be completed until completion. For example, I live in Jakarta working in Bandung every Monday morning once I have gone to Bandung to follow the flag ceremony and get the job done immediately.

As employees were essentially the importance of the organization took precedence over personal interests. Commitment, when someone decides to work, was the employee is ready to prioritize the interests of the organization in comparing personal interests.

The author tried to interview the head of administration division about the employees who left the job desk for no reason and the work was unfinished. I am as the head of administration division takes care of staffed also not a few employees who leave the job desk in a long period cause their abandoned jobs to go out for lunch or take care of personal interests for long periods. At the time the boss needed them to ask the extent of the work they had done they were not in place when the rest hours were up (interview on October 11, 2019).

The timing of the rest time was already set at 12.00 until the hour 13.00 but employees at the training center always rest often not by the schedule that has been set often break past the scheduled rest time so that the hour should have entered work but the officer still take a rest. The effort was to use the absence of rest hours so that employees were disciplined at rest hours. The author tried to ask the employee what was the staff doing when leaving the job desk for a long time and the job was abandoned by the employee saying: "Employees usually have a lot of personal interest or long time chatting to exceed the rest".

Employees spent a lot of time chatting at rest so they forget about the hours of rest. So if the superiors required the officer, they were not available.

\section{Culture Clarifies and Strengthening Behavior Standard}

The discipline of the employee both the attendance and the discipline of the ceremony was seen from his supervisor, especially the Supreme Chief, head of the training center. The Head of the training center was a role model in discipline when the head of the training center gave examples of discipline both attendance and ceremonies then the officers will feel embarrassed because they were not disciplined. The Head of the training center was the highest motivation in employee discipline. Training Center has issued a rule about the discipline of employees, especially in terms of absence as head of administration division said.

We are from the administration division has often socialized the discipline of employees through the official memorandum, through banners, employee activities held every start of the year but there are still employees who are not disciplined for a late entry into the office, go home before time, do not follow the ceremony and others (Interview on 11 October 2019).

Head of administration division said that a lot of employees were still late for work every day and late to follow the flag ceremony. Various reasons that he asked by the employee to get permission not to go to work, as said head of administration division at the time of the interview. 
A wide variety of reasons are proposed by officers to be approved for permission, especially family reasons. So we are from officialdom inevitably let them enter. Whereas we know the reason the family is a way to be issued permits not to enter the work. As well as permission to go home early because the reasons for Family Affairs "(interview on October 11, 2019).

The reason that employees often used in asking for permission was the family reason, for family reasons was the most effective reason for the permit to be approved. The organization has conveyed the rules of discipline of employees and officers had known it as the officers said during the interview: ".. yes, the organization is quite clear about the discipline of employees through socialization and banner but there are still employees who are not disciplined" (Interview on October 2, 2019).

\section{Barriers of Running Organizational Culture}

Some inputs related to existing barriers related to the culture of the Organization being conducted were as follows:

Officers still did not understand the rules of uniformly that appropriate to rules. Lacking pride of uniform as an identity symbol. Still lazy for employees to use the full attribute.

There were still employees who were more concerned about personal interests so that the work was often abandoned.

Employees often leave the job desk without any important reasons, especially at rest hours. Employees prefer to have a long chat after lunch or take care of personal affairs so that work was often abandoned.

Working without a certain program that causes the execution of training programs and delivery of training programs to the area was hampered. Many officials who were still lazy in following the flag ceremony. Because the rules that say employees who were late in the work were given a tolerance of one hour delay with the condition of officers must reimburse/pay the delay with a longer working time then a lot of employees who prefer late admission to the office with a coherency pay off on them come to the office on time.

Because of many employees who were concerned with their interests then there were some officers coming home before the time. There were still employees who often ask for permission to not go to work with the reason of the family although the importance was not the interest of the family and hope the office will continue to give permission not to work.

\section{Efforts made regarding the role of organizational culture}

Efforts made for employees to understand the correct uniform rules by sharing the right uniform example handout according to the rules.

In the employee's program held every initial year is always inserted motivation to bring pride in the use of uniform as an identity symbol.

\section{Created a reduced-office allowance rule for those who do not use full attributes.}

A direct approach from supervisor to building their subordinates to be able to work better. Attempts to remind employees of the deadline for rest hours that the organization imposed the limit of rest hours is the absence of absent and absent of return of the day after the break. With the enactment of the absence of employees will be more disciplined time and work will not be abandoned and the job completed on time. 
Coordinate with the training areas required by the area so that it can be entered into the Training Center Regional Bandung training program for the following year so there is no further revision of the training program.

Efforts made so that employees are more actively attending the flag ceremony is according to the rules of the center for those who do not follow the flag ceremony will be subject to a deduction allowance of $2 \%$ and given a letter of rebuke for who do not follow the ceremony.

For those who often late in the Office by the provisions of the Center will be subject to reduced allowances taken from late hours. Efforts made to officers who were the most prominent reduction of performance allowances subsequently approached a direct supervisor to construct the latter's subordinate letter of rebuke. Efforts made to employees who often go home early are the most important reduction in performance allowances, then the direct supervisor's approach to fostering his subordinates is issued a warning letter.

To limit the reduction of a permit for family reasons by sorting the submitted permissions by interviewing the officer who submitted the permit.

\section{Discussion}

Organizational culture is the "spirit" of the organization because there were a philosophy, vision, and mission of the organization that will be an important force for the company to compete. Organizational culture was formed from the organizational philosophy and values embraced by human resources within the organization, but the role of the leader or top management was an enormous contribution to organizational culture formation. Organizational culture should be owned by the company including government agencies so that employees have the values, norms, references, and guidelines to be implemented. The organizational culture also as an employee, conflict reducer, and employee motivator in carrying out the task well, so that positive effect on behavior and performance. A strong culture meant that all employees have the same perception of achieving organizational objectives. The unity of perception was based on the similarities of the believed value, the high norms, and the pattern of the obeyed (Darsono \& Ashari, 2010). According to Robbins (2010:50), The quality of human resources that have a strong influence on organizational performance was the organizational commitment. Employees who have a high commitment will be responsible for providing all of their skills because they felt they have an organization. The strong sense will make employees felt useful and comfortable in the organization (Robbins, 2010).

Organizational culture can affect the way people behave and should be the benchmark in any organizational development program and policies taken. This was related to how that culture affected the organization and how a culture can be managed by the organization. According to Cushway and Lodge (2000), organizational culture was an organizational value system and affected how work was done and the way employees behaved. It can be concluded that the organizational culture in this study was an organizational value system embraced by members of the organization, which then affected how it worked and behaved from members of the organization. Thus, this condition has been by the opinions of Cushway and Lodge (2000), that the organizational value system adopted by the members of the Organization in the environment of the Ministry of Home AffairsTraining Center Regional Bandung has influenced the way to work and behave from each of its employees to make the organization more creative and innovative in carrying out every vision and mission of the organization that has been.

The organizational commitment was the degree in which employees engaged in their organization and wished to remain a member, in that it contained the attitude of loyalty and willingness of employees to work optimally for the organization where the employees work. (Greenberg \& Baron 2003). In organizations, commitments were often associated with job satisfaction. The assumption the higher the employee's work satisfaction will be the higher the work 
commitment. Hearken to the existing theory, to foster identification was done by modifying the objectives of the Organization, to include some personal objectives of the members, or in other words, the organization also included the needs and desires of members in the organizational objectives. This will foster an atmosphere of mutual support among members of the organization. Further created members willingly sacrifice energy, time, and mind to the achievement of organizational objectives.

From the organizational concept theory, it has been explained that the employee's commitment was important to the organization, especially to maintain the continuity and achievement of objectives. However, to obtain a high goal, it was necessary to achieve adequate conditions.

\section{Conclusion}

Organizational culture is seen from the aspect of giving a sense of identity, role to raise commitment to the organizational mission and its role in clarifying the standards of behavior has not optimally played one role of them by not using the full attributes and not using uniforms according to the Barriers in the implementation of organizational culture, there are still employees who are more concerned about personal interests so that work is often abandoned, employees still many are lazy to follow the flag ceremony. The effort is to implement employee discipline and increase their commitment to the organization. To keep the cultural value system embedded, it is necessary to do the planting of symbols, stories, rituals, languages, role models, slogans, and ceremonial importance to form the organizational culture. The organizational culture that has been established should be adaptive and highly ethical by adjusting to the vision of the organizational mission.

\section{References}

Al Nasser, A. H., \& Jais, J. (2020). The preliminary study of organizational culture, organizational capabilities and communication to improve human resources development performances in saudi arabia: Strategic fit with higher educations as moderating variable. International Journal of Psychosocial Rehabilitation, 24(2), 2667-2676.

Cushway, B., \& Lodge, D. (2000). Organizational Behavior and Design. Jakarta: Elex Media Komputindo.

Danquah, D. O., Amankona, D., Amo, S. A., \& Belinda, B. (2018). Evaluating the Concept of Organisational Culture: Power Distance Re-modification as a Tool for Public Institution Progress in Ghana. British Journal of Interdisciplinary Research Volume 9, Issue 1.

Darsono \& Ashari. (2010). Pedoman Praktis Memahami Laporan Keuangan (Tips Bagi Investor, Direksi dan Pemegang Saham). Yogyakarta: Penerbit Andi.

Duncan, Tom. (2008). Principles of Advertising and IMC. Boston. McGraw Hill.

Ernesto, Knein., Greven, Andrea., Bendig, David., Brettel, Malte. (2020). Culture and crossfunctional coopetition: The interplay of organizational and national culture. Journal of International Management, Volume 26, Issue 2

Gibson, James. L. et all. (1995). Organizations: Behavior, Structure, Processes. New York: McGraw-Hill

Greenberg, J. \& Baron, R.A. (2003). Behavior in Organizations Understanding and Managing the Human Side of Work. New Jersey: Prentice-Hall International.

Kreitner, Robert and Angelo Kinicki. (2001). Organizational Behavior. Fifth Edition. New York: Irwin McGraw-Hill.

Manik, Ester. (2016). The Influence of Transformational Leadership on Achievement Motivation and Organizational Climate and Employee Performance. International Journal of Academic Research in Business and Social Sciences, Vol. 6, No. 12.

Morissan. (2009). Teori Komunikasi Organisas.i Bogor: Ghalia Indonesia.

Nimran, Umar. (1999). Perilaku Organisasi. Surabaya: Citra Media. 
Önday, Özgür. (2016). Organization Culture Theory: From Organizational Culture of Schein to Appreciative Inquiry of Cooperrider \& Whitney. Organizational Behaviour, 92, P. 39002-39008

Robbins, Stephen P. (2007). Perilaku organisasi. Jakarta: PT Indeks.

Robbins, Stephens, P. (2010). Manajemen. Jakarta: PT. Gelora Aksara Pratama.

Sutrisno, Edy. (2010). Pengaruh Budaya Organisasi, Stres Kerja dan Komitmen Terhadap Kinerja Karyawan CV. Bintang Karya Putra di Surabaya. Ekuitas Vol. 14 No. 4.

Sun'an Ahmad, (2010). Budaya dan Iklim Organisasi. Bandung: Mandar Maju.

Suyono, Bambang. (2004). Menumbuhkan Budaya Kerja yang Kompetitif'. Jurnal Bisnis dan Manajemen, Vol. 1, No.1 